\title{
Article
}

\section{Emerging third-sector sports organisations and navigating uncertainty in an 'era of austerity': a single ethnographic case study from Liverpool}

Kenyon, James Andrew, Mason, Carolynne and Rookwood, Joel

Available at http://clok.uclan.ac.uk/21468/

Kenyon, James Andrew, Mason, Carolynne and Rookwood, Joel ORCID: 00000002-6510-4519 (2018) Emerging third-sector sports organisations and navigating uncertainty in an 'era of austerity': a single ethnographic case study from Liverpool. International Journal of Sport Policy and Politics, 10 (1). pp. 1-18. ISSN 1940-6940

It is advisable to refer to the publisher's version if you intend to cite from the work. http://dx.doi.org/10.1080/19406940.2018.1425732

For more information about UCLan's research in this area go to http://www.uclan.ac.uk/researchgroups/ and search for <name of research Group>.

For information about Research generally at UCLan please go to http://www.uclan.ac.uk/research/

All outputs in CLoK are protected by Intellectual Property Rights law, including Copyright law. Copyright, IPR and Moral Rights for the works on this site are retained by the individual authors and/or other copyright owners. Terms and conditions for use of this material are defined in the policies page. 


\title{
Emerging third sector sports organisations and navigating uncertainty in an 'era of austerity': a single ethnographic case study from
}

\section{Liverpool}

\author{
James Andrew Kenyon ${ }^{\mathrm{a} *}$, Carolynne Mason ${ }^{\mathrm{a}}$, Joel Rookwood ${ }^{\mathrm{b}}$ \\ ${ }^{a}$ School of Sport, Exercise and Health Sciences, Loughborough University, UK; ${ }^{b}$ School \\ of Sport and Wellbeing, University of Central Lancashire, UK \\ *Corresponding author, School of Sport, Exercise and Health Sciences, Loughborough \\ University, Loughborough, Leicestershire, LE11 3TU, UK, J.A.Kenyon@lboro.ac.uk
}

There have been a number of recent policies in the UK which have attempted to capitalise on the benefits that sport potentially offers for health and wellbeing. These are, however, set against a somewhat incongruous backdrop of reductions in opportunities to participate, resulting from the ongoing constraints on public spending associated with austerity. In response to these constraints, an increasing number of third sector sports organisations (TSSOs) have emerged to fill some of the gaps left by the public services that local authorities are no longer able deliver. This research draws on the experiences of one of those TSSOs, Target Football, a Community Interest Company located in Princes Park, Liverpool, one of the most deprived neighbourhoods in the UK. Drawing upon six-years of ethnographic research, and a posteriori semi-structured interviews, this paper examines the ways in which this TSSO has navigated - and continues to navigate - the contextual uncertainty arising from austerity, to sustain sports provision in an environment where opportunities have declined in recent years. Underpinned by stakeholder theory, this research examines the relationships that exist between organisations and their stakeholders, and frames these in relation to power, 
legitimacy, and urgency. The findings provide insight into the significant obstacles that challenge the survival of TSSOs in the context of a scarcity of resources. From a more practical perspective, these findings also provide critical insight into David Cameron’s aspiration ‘to do more with less'.

Keywords: austerity; community sport; stakeholder theory; third sector sport organisations

\section{Introduction}

Poverty and social exclusion from sport are inextricably linked (Collins and Haudenhuyse 2014). It is perhaps not surprising then that whilst the impact of the 'era of austerity' on sport and leisure provision within the UK is not yet well-understood, there is increasing evidence indicating that its effects are being disproportionally felt by disadvantaged communities (Asenova, Bailey, \& McCann, 2015, Hastings et al., 2013, 2015, Jones, Meegan, Kennett, \& Croft, 2015). A number of recent UK policies (for example, Creating a Sporting Habit, Sporting Future, Towards an Active Nation) have attempted to capitalise on the benefits that sport potentially offers for health and wellbeing. Yet these are set against a somewhat incongruous backdrop of diminishing opportunities to participate, resulting from austerity-led reductions in public funding (Parnell et al. 2014). In response to such reductions, an increasing number of third sector sports organisations (TSSOs) have emerged to fill some of the gaps left by the public services that local authorities are no longer able to deliver. Although this is not a new development, a greater level of importance has been placed on such organisations in the past twenty years, fuelled initially by New Labour's restructuring of welfare and public service provision, and then accelerated by Conservative-Liberal Democrat post2010 austerity measures (Jones et al. 2015). However, according to Hayton and Walker 
(2016, p.99), there is evidence suggest that these TSSOs, and other 'third sector organisations (TSOs) such as charities and voluntary service organisations have had funding/grants reduced or rapidly rundown, affecting their ability to deliver services’. With that in mind, the recent literature has aimed to document the negative effects of austerity both in sport (Parnell et al. 2014) and in other contexts (Hastings et al. 2013, 2015, Jones et al. 2015, Kennett et al. 2015). Furthermore, the impact of austerity on TSSOs and the resulting attempts to navigate the consequences of austerity have also been the subject increasing academic attention (see, for example, Hemmings 2017, Egdell \& Dutton, 2017). Thus, an objective of this research is to contribute toward this growing literature base. Recent policy changes have compounded the impact of austerity furthering the creation of an uncertain and unstable environment for TSSOs to operate within. Thus, the following research question broadly underpins the present study:

How does a third sector sports organisation survive, and achieve its aims and objectives in such turbulent, and increasingly resource-constrained, contexts?

This research draws on the experiences of Target Football, a Community Interest Company (CIC) ${ }^{1}$ which was established in 2010 as a direct consequence of the ongoing constraints on public spending associated with austerity. Located in Princes Park, Liverpool, this TSSO is based in one of the most deprived neighbourhoods in the country (top 1\%) (Department for Local Communities and Government 2015). Drawing upon ethnographic research, and underpinned by stakeholder theory, this paper examines the ways in which Target Football has navigated - and continues to navigate the contextual uncertainty arising from austerity to sustain sports provision for local people in an environment where accessible opportunities to partake have declined in 
recent years (Parnell et al. 2014). Thus, the objectives of this research are two-fold: a.) to investigate some of the most significant obstacles that challenge the survival of Target Football and the ways in which their managers navigate these; and, b.) to determine some of the resultant implications for young people’s participation in sport and leisure in a disadvantaged community. In achieving these objectives, it aims to add to the literature base concerning austerity-driven policy and changes in sport, and TSSOs. From a more practical perspective, the paper also aims to provide critical insight into David Cameron’s aspiration ‘to do more with less’ (in Krugman 2015, p.1).

\section{Literature Review}

\section{The impact of deprivation and austerity on sport and leisure provision in}

\section{Liverpool}

The city of Liverpool is situated on the banks of the River Mersey in the North-West English county of Merseyside. In 2008, it became the first English city designated as a European Capital of Culture, a title awarded primarily in recognition of its flourishing cultural achievements during the second half of the twentieth century - particularly relating to musical, sporting, and other entertainment engagements and accolades (refer, for example, to: Belchem 2000, 2006, Cowley et al. 2001, Long and Williams 2005; Hudson, 2006). During the same period, however, Liverpool experienced a socioeconomic implosion which brought about the city's decline from 'the mightiest seaport [in] the world' (Belchem 2000, p.20) to one of UK's most deprived local authorities (Department for Communities and Local Government 2015). Throughout the 1960s, 1970s and 1980s, Liverpool’s socio-economic disintegration resulted from containerisation in global shipping and changes in the UK's trading partners ${ }^{2}$, combined 
with Conservative-led deindustrialisation, economic restructuring, and reductions in state welfare.

The tens of thousands of city-wide redundancies resulting from the closure of hundreds of factories (Murden 2006) and a decimated maritime industry which had been based upon casual employment practices meant that between 1971 and 1991 the unemployment rate in the city rose from 10.6\% to 21.6\% (Census 1991) - with figures as high as 50\% around the city’s docks (Murden 2004). Economic marginalisation, ghettoisation, and social deprivation throughout sizeable parts of the city occurred during the 1980s (Uduku 1999, Murden 2006, Boland 2008) with the 1981 Toxteth Riots, and dominance of the Trotskyist 'Militant' group in the city council (between 1983 and 1987) proving symptomatic of the socio-economic and political challenges the city experienced throughout the decade. By 1985, between $15 \%$ and $20 \%$ of the land within the city limits was either derelict or unused (Bichard 2016), and throughout the 1980s approximately $12 \%$ of the city’s population out-migrated in search of improved employment opportunities elsewhere (Ferrari and Roberts 2004, Meegan 2004).

When such patterns continued into the 1990s, Merseyside became eligible for European Union (EU) Objective 1 Structural Funds in which $£ 1.6$ billion of 'matched' aid was made available to the county between 1994 and 1999 (Boland 2000). By the end of the 1990s, therefore, the city had begun to experience a 'possible reversal of 30 years of unabated economic decline' (Jones and Wilks-Heeg 2004, p. 345) as EU funding and general economic recovery combined with 'aggressive place marketing' (Boland 2008, p. 357) linked to the architectural heritage of Liverpool's Victorian heyday helped present the city as a more attractive location for private sector developers (see, for example, Sykes et al. 2013). The significance of Liverpool’s architecture was further underlined in 2004, when sections of the city-centre were awarded UNESCO 
World Heritage Site status, which also contributed to the city’s designation as the 2008 European Capital of Culture ${ }^{3}$. The revival saw a significant physical regeneration of the city centre and the development of a visitor economy (Kennett et al. 2015).

Despite this seeming reversal of fortunes, the economic and political conditions imposed following the 2008 global economic crisis and the Conservative-Liberal Democrat Coalition Government's post-2010 austerity measures resulting from the 2010 Comprehensive Spending Review (HM Treasury 2010), have significantly and disproportionally impacted upon Liverpool (see, for example, Jones et al. 2015). For example, between 2010/2011 and 2014/2015, the city experienced the greatest reduction in central government funding of the country’s eight core cities (Kennett et al. 2015). Between 2010/2011 and 2016/2017, Liverpool City Council was forced to reduce its annual spending by an average of approximately 58\% (Guardian 2015), over 20\% above the national average (National Audit Office 2014). This problem is aggravated by the fact that a significant percentage of the City Council’s budget is funded by central government (72\%), as a substantial proportion of Liverpool's residences are located in lower Council Tax bands (Liverpool City Council 2016); that is, comparatively less income is raised through local taxes. Thus, although the various effects of such reductions in central government funding have been explored elsewhere (see Jones et al. 2015, Kennett et al. 2015, Parnell et al. 2014), such is the significance of that impact overall that a recent Annual Audit Letter for Liverpool City Council produced by Grant Thornton (2015) questioned the Council’s ability to provide any discretionary services in 2017/18, and suggested that by 2018/19 mandatory services would also be under threat.

The situation is exacerbated by Liverpool having the largest number of neighbourhoods - or Lower Super Output Areas (LSOA) ${ }^{4}$ - in the most deprived one 
per cent of neighbourhoods nationally, and almost two-thirds of the city's population (61\%) live in the most deprived twenty per cent (Department for Local Communities and Government 2015). Specifically, the most severe deprivation in the city is evident in residential areas encircling the city centre, including Princes Park (Liverpool City Council 2015). This has been an emerging problem since the 1970s, particularly in the context of notable economic decline (Boland, 2007). A significant historical dependence on public sector employment resulted in an austerity-instigated loss of almost 9,000 full-time jobs, equating to double the national rate (Kennett et al. 2015). The growth in private sector employment has risen, but does not mirror these job losses, whereas part-time positions have remained relatively constant in Liverpool (Kennett et al. 2015).

Despite its recent improvement then in overall rank in the English Index of Multiple Deprivation (IMD) - moving from first place (i.e., the most deprived city in the country) in the 2004, 2007 and 2010 iterations of the IMD, to fourth in 2015 (Communities and Local Government 2004, 2007, Department for Local Communities and Government 2010, 2015) - the city still contains some of the most disadvantaged areas in the UK in terms of employment and income. Income deprivation is one of seven domains of deprivation which combine to form the IMD, the other domains being: employment deprivation, education skills and training deprivation, health deprivation and disability, crime, barriers to housing and services, and living environment deprivation (Wright et al. 2006). Along with employment deprivation, income deprivation serves as the most significant component of the IMD. Public health is another element of concern in this context, with recent scores indicating that some of the UK's least favourable health-related variables (namely children’s BMI scores, waist 
circumference and cardiorespiratory fitness) have been found amongst youth populations in areas of high deprivation in Liverpool (Noonan et al. 2016).

Income deprivation has also been found to have a considerable effect on young people's access to sport and exercise in Liverpool, although the issue is not confined to this specific city. Variable access to financial resources and sports facilities have been found to promote health inequalities with respect to involvement in sport and physical activity in a number of cities across the UK, including: Glasgow (Macintyre et al. 2008), Bristol (Jones et al. 2009), Manchester (Blakeley and Evans 2013), Norwich (Panter et al. 2008), Birmingham (Collins and Kay 2014), Cardiff (Higgs et al. 2015) and Liverpool (Parnell et al. 2014). The connection between income deprivation and youth access to sport in British localities is often dependant on whether the context is urban or rural, the travel-time threshold, and whether the facilities are private or public (Kelly, 2010). However, few studies have examined the type and quality of sport facilities in relation to the socio-economic status of the respective locality from a UK perspective (Higgs et al. 2015).

The lack of recreational facilities in a specific location has long been considered to impact people's perceptions and use of those facilities (Jackson 1994). Moreover, the range of facilities and resources which might promote health are typically less common in poorer areas (Macintyre et al. 2008). Financial affordability is also considered to be another causal factor of lower levels of physical activity in deprived neighbourhoods (Evans et al. 2013; Kokolakakis et al. 2014). Farrell et al. (2013, p.55) also found household income to be 'strongly associated with inactivity even when controlling for local area deprivation', as well as education. As Wilkinson (1996, p. 230) notes: ‘There can be virtually no one who is poor and not excluded from leisure and culture, for much of leisure is commodified and has to be paid for directly, or indirectly.' This argument 
remains relevant two decades later. In Liverpool, reductions in local authority budgets have led to cuts to various municipal sports facilities threatened with closure including swimming pools and leisure centres (King, 2009; 2013). The community provision of established sports clubs - notably private enterprises such as Everton Football Club have implemented various health promotion and improvement interventions (Richardson \& Rookwood 2008; Curran et al. 2014). However, the shift in management and responsibility from local authority to private enterprise has had various consequences pertaining to access and participation in grassroots sport and physical activity (Parnell et al. 2014).

The closure and changing practices of municipal sport centres has had a particular effect on Liverpool's youth population. In schools also, there are numerous challenges in delivering high-quality PE to young people which are further exacerbating such effects. For example, Rainer et al.'s (2012, p.437) research found that, among other issues, ‘insufficient space and inadequate facilities', which are often in high demand and subject to timetabling restraints, were of particular concern to the primary school headteachers interviewed by the authors. Young people aside, other demographic segments of Liverpool's population also face problems connected to income deprivation and access to physical activity. The scarcity of resources to sustain physical activity amongst aging populations, for instance, renders the challenge of sustaining active ageing particularly prominent in Liverpool (Barrett \& McGoldrick 2013). Related obstacles are also evident in the context of disability sport in Liverpool, where the impact of government cuts to public funding have similarly been experienced. The Greenbank Sports Academy (GSA) in the south of the city is a notable example. The GSA is a TSSO that not only provides opportunities for people with disabilities to partake in sport and recreation, but also serves as a dedicated centre of elite 
performance for disability sport across the north of England. As Walker and Hayton (2016, p. 7) note, most of the challenges facing the GSA can be 'reduced to the availability of financial resources.' Extending that research then, the present study draws on the experiences of another TSSO from the city, Target Football. But before outlining the organisation and discussing methodological approach, the following section presents the theory and framework against which the research was analysed.

\section{Stakeholder Theory and Stakeholder Salience: An Analytical Framework}

In his seminal text, Freeman (1984) proposed that organisational success was linked directly to meeting the needs, goals, and motivations of all its stakeholders thereby challenging the prevailing belief that owners/shareholder's needs should be prioritised. Stakeholder theory proposed that managers who were proactive in identifying and responding to stakeholder needs were more likely to make decisions that enabled the organisation to successfully meet its aims and objectives. Freeman (1984, p.46) offered a broad definition of the term stakeholder as 'any group or individual who can affect or is affected by the achievement of the organization's objectives,' but others have offered narrower definitions in recognition that these have greater practical application for managers. Clarkson (1995) distinguished between 'primary' and 'secondary' stakeholders with the former being characterised as being integral to the survival of the organisation and therefore taking precedence over the latter.

Identifying and prioritising stakeholders and their needs presents challenges for managers. Mitchell et al. (1997) developed a typology for managers to use in order to identify relevant stakeholders and a theory of salience in order to prioritise stakeholders where salience was defined as 'the degree to which managers give priority to competing stakeholder claims’ (1997 p.854). In so doing their work provided a basis for further 
research aimed at examining how, and under what circumstances, managers can and should respond to various stakeholder types in order to realise organisational objectives.

Mitchell et al. (1997) proposed that in order to evaluate the stakeholder-manager relationships systematically, three attributes were relevant by nature of their relative absence or presence namely: power, legitimacy, and/or urgency. Power is concerned with the level of influence stakeholders have over the organisation. Mitchell et al. (1997) argued that power is both defined and exerted by stakeholders in various different guises. Drawing on Etzioni (1994) they suggested that power can be classified according to the type of resource used to exercise power. Coercive power results from physical action, Utilitarian power results from material or financial resources whilst normative power is derived from symbolic resources.

Whilst Mitchell et al. (1997) noted that the legitimacy of stakeholders is necessarily connected to power, they argued that this should receive separate attention. Despite the debates around whether legitimacy derives from normative declaration (Donaldson \& Dunfee, 1999) or other bases Mitchell et al. (1997) instead opt for Suchman's socially constructed definition of legitimacy as 'a generalised perception or assumption that the actions of an entity are desirable, proper, or appropriate within some socially constructed system of norms, values, beliefs and definitions’ (1995:574).

The final element of the typology concerned the urgency of stakeholders' claims. Urgency is concerned with two elements, namely: time-sensitivity and degree of impact (Mitchell et al. 1997). Mitchell et al. (1997) argue that it is the combination of these two elements that determines the degree to which stakeholder claims require urgent action from the organisation and therefore this element is also relevant to determining stakeholder salience at a particular point in time. 
The Mitchell et al. (1997) typology proposed four distinct stakeholder types according to the number of attributes the stakeholder possessed. Specifically, 'nonstakeholders' possess none of the three attributes, 'latent stakeholders' possess one attribute, ‘expectant stakeholders’ have two, whilst 'definitive stakeholders’ possess all three attributes. Definitive stakeholders were characterised as having the greatest salience to the organisation (as a result of their power, legitimacy, and urgency) and therefore Mitchell et al. (1997) argued that these were the stakeholders that managers should focus their attention on primarily in order to ensure organisational success. They also argued however that stakeholder salience is dynamic as possession of the attributes can vary over time and because the relationship between the stakeholder attributes and their salience is mediated by the individual managers of the organisation.

Building on the work of Mitchell et al. (1997), Friedman et al. (2004) proposed that stakeholder theory had relevance to sports managers attempting to manage issues that could potentially impact on their organisational success recognising that stakeholder theory does not comprise of succinct, testable hypotheses but instead enables 'the categorization and description of groups and individuals in a given organizational environment' (2004, p. 171). Using the concepts of power, legitimacy, and urgency in order to examine stakeholder salience in the context of issue management, Friedman et al. (2004, p.172) aimed to provide a useful framework for sports managers to make 'better tactical and strategic decisions as they work towards their organisations short- and long-term goals’.

Parent and Deephouse (2007) argued there had been a lack of practical application of the Mitchell et al. (1997) framework as a tool for empirical analysis. In their study of large-scale sporting event organising committees, they focused on individual managers' views on stakeholder power, legitimacy, urgency, and salience, 
thereby prioritising the ‘stakeholder-manager relationship’ over the stakeholderorganisation relationship. In so doing they supported Harvey and Schaefer (2001) who argued that it is managers' perceptions of stakeholder influence, rather than any objective measurements of attributes, that determine the response of sport managers to stakeholders.

The potential value of stakeholder theory to managers of third sector organisations was recognised by Taylor and Taylor (2014) who argued that third sector organisations are typically accountable to a much wider range of stakeholders than more profit-driven organisations. These authors also argued that the needs of funders can potentially be prioritised by managers of third sector organisations (TSOs) in the UK over the needs of other stakeholders - including the beneficiaries of the services offered by TSOs.

This study examines the usefulness of the Mitchell et al. (1997) framework in understanding how the founders (managers) of Target Football have responded to the impact of austerity and the changing policy context. In so doing it focuses on the founders' perceptions of stakeholder-manager relationships highlighting the dynamic (and subjective) nature of stakeholder salience.

\section{Target Football CIC, Liverpool, UK}

Target Football is a CIC based on Admiral Park Recreation Ground in the inner-city district of Toxteth, immediately south of Liverpool city centre. It is located in that aforementioned inner-city core of the most severely deprived parts of the country (top 1\% nationally), on the border of Princes Park and Riverside (DCLG, 2015). Established in 2010, its two founders were both previously employed on separate Liverpool-based social inclusion projects - Nacro $^{5}$ and the Merseyside Youth Association ${ }^{6}$ (MYA) - in 
roles that supported the sporting elements of their respective employers' ambitions. These roles, for both founders, were mainly focussed around providing out-of-school diversionary activities and football development programmes in the inner-city areas of Kensington and Toxteth to young people deemed 'at-risk'. Having both been made redundant due to austerity-induced reductions in funding to such organisations from local government, a meeting between the two in 2010 provided the motivation to set-up a new joint project that would aim to fill the gap left behind by their employers' cessation of such services.

Utilising donated unused office space at Park Road Sport Centre (or Lifestyles Park Road), the two founders of Target Football initially undertook school holiday sports activities at the Centre, funded by Liverpool City Council, and offered paid-for weekend coaching sessions, both of which were primarily aimed at young people from the local area. As the sessions became more popular, charitable funding grants financed the expansion of the services offered and the projects delivered (see tables $1 \& 2$ ). In 2012, Target Football relocated to nearby Admiral Park, and upon doing so, began managing the sports facility located on the site on behalf of the owner, the Plus Dane Group - a social housing management services organisation operating primarily in the north-west of England. The facility includes a portable office, grass football pitches, a multi-use hard court area, and a modern changing pavilion. Several years on Target Football currently uses these facilities to deliver a programme of subsidised and paidfor football services, as well as fully-funded projects that aim to address local community issues relating to education and employment, social inclusion, health, and equality (see table 1 for examples). Rental income from hiring out the grass pitch facilities, along with grant money, provides salaries for its two directors and supports 
five sessional coaches. Target Football also receives support from a further ten volunteer coaches and organisers.

[INSERT TABLE 1]

[INSERT TABLE 2]

\section{Methods}

The research that has informed this discussion was derived using a mainly ethnographic case study approach in order to explore the ways in which Target Football has navigated - and continues to navigate - contextual turbulence in order to sustain sport-based development programmes for one of the UK's most disadvantaged communities. The value of ethnography in conducting exploratory research to examine social processes such as navigating austerity - was noted by Fielding (1993, p.157) who stated, 'As a means of gaining a first insight into a culture or social process, as a source of hypotheses for detailed investigation using other methods, it is unparalleled.' Thus, given the lack of research in the area - that is, research on the impact of austerity on TSSOs and the resulting attempts to navigate the consequences of austerity - this ethnographic approach was considered particularly useful in capturing the perceptions, experiences, and meaning-making of Target Football's various stakeholders in relation to the study's broad aim.

Between February 2011 and November 2016, the first author engaged with the project through casual, ad-hoc consultation. The nature of this consultation involved supporting the organisation with bid-writing, web development, monitoring and evaluation, and editing. Throughout this period the author also collected field notes, informally questioned relevant adult stakeholders ${ }^{57}$, recorded personal reflections, and engaged in participant observation at Target Football. In light of the significant 
contextual changes in Liverpool outlined above, the ethnographic data collection was supplemented by a posteriori semi-structured interviews with the organisation's founders, conducted by the second author. These interviews both encouraged the founders to reflect on their experiences of sustaining a TSSO within a context of ongoing reductions in public funding and continuing austerity, and examined '...the organization itself, the stakeholders, and the relationship between the organization and its stakeholders' (Mitchell et al. 1997). After producing verbatim transcriptions from the recorded interviews and field notes, the data was then analysed against the stakeholder theory analytic framework. That is, portions of the data were de-contextualised from their original interview or ethnographic context and then re-contextualized into one of the three stakeholder theory themes proposed by Mitchell et al. (1997): power, legitimacy, and urgency. Finally, in line with Walker and Hayton's research into the GSA, respondent validation was also undertaken, in which the project founders 'were approached to 'check' the accuracy and acceptability of the research findings' (2016, p 104). Direct references to the data in the following sections are expressed with an indication of the role of the respondent followed by an indication of the type of method employed to collect that specific data (FIV, formal a posteriori interview; EIV, ethnographic informal questioning; and, EO, ethnographic observation). For example: (Founder \#1, EIV).

\section{Findings}

\section{Target Football: a successful TSSO?}

Prior to examining stakeholder salience through the themes of power, legitimacy, and urgency, this first section of the findings considers the efficacy of Target Football in 
meeting its organisational aims and objectives and thereby identifies the parameters against which the organisation can be described as 'a success'. In doing so, the data arising from the ethnographic field work and the associated reflections of the first author are summarised. While the longevity of the Target Football project (2010 to present), and its founders' proven aptitude for effective bid-writing (see table 1) might be considered achievements in their own right, analysis of the data revealed three broad themes around which the organisation might also be considered successful.

The first of these themes relates to facilities and equipment, and at various points throughout the data collection period, informal questioning of stakeholders concerning their perceptions of the Admiral Park site revealed broad agreement that the facilities were excellent. Target Football's programme of services and projects (see tables 1 \& 3) offer a varied range of residents from the local community the opportunity to participate on well-maintained grass pitches which are otherwise in short supply in the local area. Since taking it over, Target Football's founders have invested significant resources into maintaining and improving the Admiral Park site, which has been recognised by the Football Foundation, who on behalf of the Premier League and FA Facilities Fund, awarded the facility the highest possible rating (5/5 - 'exceeds expectations') in a 2015 Monitoring and Evaluation site visit (the experienced assessor mentioned during the visit that this was the first time he had awarded such a rating [Grant Manager, EO]). For local schools, access to high quality and local facilities is regarded as particularly beneficial. Mirroring the findings of Rainer et al. (2011), many schools in the Princes Park, Riverside, and Kensington wards of the city (i.e., those adjacent to Admiral Park) have limited and/or poor standard on-site facilities for the delivery of PE and extra-curricular sport sessions given the lack of space resulting from their proximity to Liverpool's city centre. For example: 
'Before we came here [played in this league], it was tough for us, we had to sort our own pitches out, which meant travelling all over the city. We've only got a [concrete] yard [at our school], we're in the inner city, and you can’t do a lot on it. But the pitches, all the gear [equipment]... the changies [changing rooms], they're boss, aren’t they?' (School PE Co-Ordinator, EIV).

This quote also highlights the second 'success' theme to emerge from the data in which Target Football can be said to be achieving its aims by meeting the needs of its stakeholders; that is, the cost of participation. For funded and subsidised projects, there is little, if any, financial cost for participants. Given the earlier issues then raised in the literature review relating to financial affordability and participation (see Evans et al. 2013), what Target Football is able to provide is invaluable for service- and facilityusers in this area of this city. In common with other schools (Rainer et al., 2011) school staff who use Admiral Park highlight the costs associated with the renting of appropriate facilities, travel, and the hiring of specialist coaches as being particularly problematic in providing high quality PE and sport provision for their pupils. For those schools that participated in Target Football’s Primary Schools Football League during the BIG Lottery Reaching Communities funding cycle (2013-2016, see tables 1 and 2), there was no cost - not in terms of pitch hire, coaching payments, subscriptions, or referees' fees charged by the organisation, nor, for the most part, in terms of travel to the Admiral Park site (many of schools were within walking distance). Thus, school-based stakeholders perceive Target Football’s low-cost, high-quality offerings as key in differentiating the organisation from its competitors. For example:

'It's free coaching available to us. Other similar organisations in the city have moneymaking as a priority. The school has to cough up or the children have to cough up. It's hard when it's like that' (PE Teacher, EIV). 
'Other [primary school] leagues [in the city] are like, 'Here’s your fixtures, go and sort yourself out'. There is no support with pitches, and you didn't know - half the time - where you'd end up playing, or even if we would. It was badly organised' (PE Teacher, EIV).

In addition to schools benefiting from low-cost, high-quality sports provision, Target Football's provision of Detached Football (see table 2) offers opportunities for the local community. These free evening football sessions provide supervised diversionary activities for local young people, where such opportunities had previously been on the decline. After the cessation of the nearby Dingle Community Football project in 2009 which had provided similar offerings to Target Football (Founder \#2, EIV), anecdotal observations surfaced from those in the local community suggesting that the number of young people 'hanging about on Park Road with nothing better to do' was on the rise (Parent, EO). With economic factors (i.e., income deprivation) having been shown to impact negatively upon sports participation (Kokolakakis et al. 2014) and inactivity (Farrell et al., 2014), free supervised football sessions, are valued: ‘because if they're not playing football, they'd be out on the streets, or in the house sitting on the PlayStation’ (Outreach Worker, EIV).

The final theme to emerge from the data relates to engagement and impact. Through delivering its sports-based projects and services, Target Football's aims are:

'...to make a difference to the lives of people in Liverpool by using the project as a tool to address problems they face in their community. We aim to use the power and popularity of football to encourage people to participate in safe, structured, and healthy activities that contribute to their educational development and improve their ability to connect with others from different backgrounds. By engaging 
people in community-based activities we aim to improve their social skills and increase their confidence and self-esteem so they are less likely to drift into antisocial or risk-taking behaviours' (Target Football, n.d.)

In setting out to achieve these aims, Target Football is considered to have 'reinvigorated' both school and grassroots football in local area to the degree that were its activities were to cease, 'this part of the city would lose its football heart' (Adult Participant, EIV). From a participation perspective, perhaps the most illustrative demonstration of success in this area can be seen in the number of people that Target Football has engaged with through their services and projects. Taking the BIG Lottery Reaching Communities fund as an example, in their Monitoring and Evaluation end-ofproject report to the National Lottery, Target Football reported that the number of participants on services and projects totalled over 1500 during the funding cycle (20132016, see table 3). Yet many of the projects and services Target Football (table 2) provide more than just participation-related benefits to attendees, and efforts have been made at various points to incorporate a wider holistic programme of community development into Target Football’s activities. For example, the Detached Football project included visits by trained representatives from external organisations such as Connexions ${ }^{8}$, Addaction ${ }^{9}$ and Active $8^{10}$, who offer support to young people across a range of issues including: employment, education and training, substance misuse, and health and wellbeing. Thus, through facilitating such engagement between these stakeholders, Target Football is endeavouring to make good on the above cited aims. [INSERT TABLE 3]

\section{Stakeholder Theory Analysis}

The founders of Target Football were able to identify a number of stakeholders who 
affect, or were affected by, the achievement of the organization's objectives. The claims of these stakeholders on the organisation are examined in relation to attributes of power, legitimacy, and urgency by examining the relationships between Target Football and the identified stakeholders. Children, young people and their communities and the many funders who have supported the work of Target Football were perceived to be definitive stakeholders possessing all three attributes of power, legitimacy, and urgency. Examples of expectant stakeholders were local schools, the police, and a network of local facility operators by nature of possessing only two of the three attributes currently. The fluidity of these relationships and the salience of the different stakeholders over time were however apparent.

\section{Power}

In keeping with other TSOs (Taylor and Taylor, 2014) the most significant stakeholder identified for Target Football by the founders are the beneficiaries of their work that is the children and young people who engage in the wide range of sport-based activities that Target Football offers to its local community ('I think it would be young people, children and adults, you know, they're the biggest group that benefit from the work that we do’ [Founder \#1, FIV]). Children and young people exert their normative power through their engagement, or lack of engagement, with the programmes that Target Football deliver, and the founders of Target Football are experienced in knowing how to create successful engagement programmes ('We've learnt from, you know, our own mistakes and other people’s mistakes, what young people want’ [Founder \#1, EIV]). The success of the organisation is defined by its ability to recruit and retain children and young people, and their communities, in sport-based activities that result in positive social outcomes. 
As a TSSO, Target Football have traditionally been reliant on securing revenue from grants and have been successful in accessing approximately £390,000 from supporters including Community Foundation for Merseyside, Sport England, Children in Need, BIG Lottery Fund, and Lloyds Social Entrepreneurs Programme (refer to table 1). The funders who support Target Football exert utilitarian power as a result of their ability to award - or not award - funding to Target Football and also in controlling the types of funding that are on offer. Funders also determine the scope of the projects that can be funded and the outputs and outcomes that are expected to be realised through the funding. Despite their many successes in securing funding that aligns with their aims and objectives, Target Football operates in a precarious and unpredictable environment and the founders are very aware of the need to generate alternative funding streams. Currently the founders spend $50 \%$ of their time on bid-writing related activities which is characteristic of other third sector organisations (Hastings et al., 2015). As the founders note, operating in a more commercial manner is extremely challenging in the context in which the organisation operates, where the full cost of activities cannot be borne by the families that benefit from them. If the full cost of the activity was charged this would prevent young people from being involved due to financial constraints on local families and this would challenge the organisation to achieve its aims and objectives. In the longer term the founders hope to develop the Admiral Park facility, where they are located, for hire in order to generate a sustainable income and greater security for them, their coaches and for the organisation. The income derived from commercial lettings would be used to cross-subsidise the activities that are offered to local children, young people, and their families.

The founders have however been proactive in identifying and accessing other income as a result of building up good relationships with local schools who now buy-in 
services from Target Football that were previously proven to have value to the schools when they were developed and delivered through grant funding (Founders \#1 \& \#2, FIV, EIV, EO).

\section{Legitimacy}

As a result of the social aims and objectives of TSOs the range of organisations potentially having legitimate claims on the organisation can be much broader and diverse than for other types of organisations and this presents challenges for managers in determining stakeholder salience. Taylor and Taylor (2014) argue that within the third sector multiple stakeholders will have competing needs for the organisation and that funders' needs may be prioritised over other legitimate claims as a result of their utilitarian power. In accounting for their success in navigating the challenges of austerity, the founders argue that Target Football has managed the competing claims of its stakeholders by ensuring that legitimacy is prioritised in relationships with its stakeholders 'We're always here and ... we've set the standard' (Founder \#2, FIV). This quote refers both to the relationships with children, young people, and their communities and with the funders that have supported them over the years. The developing relationship with local schools is also founded on legitimacy in the sense that schools have chosen to buy-in the services of Target Football because they have demonstrated they can deliver what the schools need.

Another way in which the importance of legitimacy is demonstrated is in Target Football's relationship with other TSSOs locally. The Liverpool 8 Sports Facility Partnership was established in 2014 following an award from Sport England's Community Sport Activation Fund. Target Football were one of the eight sports facilities involved in delivering activities to young people aged 14 and over. In spite of 
the funding finishing, the network is still in existence and is proving to be mutually beneficial to the organisations involved as they try and survive in a context of austerity. The relationships between the organisations are increasingly complex however as noted by the founders who describe the other organisations as both 'partners' and as 'competitors'. The reduction in funding opportunities has resulted in greater competition to access the remaining resources:

\footnotetext{
'Everybody’s sort of looking at going for the same funding...Everybody’s looking to see what you're doing, no one's even, nobody wants to sort of duplicate what you do but sometimes they have to...You know sometimes they're trying to keep themselves in a job’ (Founder \#1, FIV).
}

\section{Urgency}

Urgency along with power and legitimacy is relevant to determining the salience of different stakeholders within a changing context. An example of when there was a significant shift in stakeholder salience as a result of 'urgency' was in the summer of 2011 when there were riots involving young people in Toxteth when the organisation's survival was threatened. Local authority and other funders' resources were channelled away from existing projects into developing regeneration projects that were collectively aimed at responding to the underlying causes of the riots and this necessarily impacted on organisations like Target Football who lost funding with very little notice. The salience of funders who no longer supported Target Football diminished and as alternative funding was sought elsewhere new funders increased their salience as a result of the urgency to secure the financial security of the organisation. The experience highlights the inter-play between power, legitimacy, and urgency and also the vulnerability of TSSOs and indicates that those who are able to adapt quickly may be 
more likely to survive in the longer term.

Counter-intuitively the founders of Target Football did not characterise their response to the recent round of austerity as being time-sensitive in the sense that they perceive it not to be anything new for them to respond to ('Because we started in such tough times, neither of us knows any different ... I haven’t reacted to austerity this time around because it's just do what you do' [Founder \#2, FIV]). The degree of impact of austerity is however increasingly challenging as a result of the reduction in other services locally.

\footnotetext{
'Austerity has been pretty much the main issue that we’ve been battling against because there's more organisations going for smaller pots of funding. With the cuts that have kicked in over the years there's been less provision because local government and youth services have been drastically, drastically cut back, more I think, more in this city than anywhere else in the country. So, there's a lot more young people with less activities available to them. So, you know we're always trying to find different ways to engage them' (Founder \#1, FIV).
}

Despite the pressure they are under the founders have refused to be swayed from their original aims and objectives and they perceive that to be instrumental in accounting for their success:

\footnotetext{
'We're quite methodical in what we do, and we don't try and do it too quickly, you know too soon, and we don't run before we can walk, and I think that's what ... we were only discussing it the other day actually about how some people want things yesterday. We've always sort of taken our time to build things up properly. But you know the ongoing challenge for us is to sustain ourselves as workers because without me and Reg there's no company and therefore there's no programmes for the community' (Founder \#1, FIV).
} 
This steadfastness has not been without risk however as there have been times when the founders paid themselves on a month by month basis as this was the only way the organisation could survive.

\section{Discussion and Conclusion}

This paper examined how a third sector sports organisation has survived - and achieved its aims and objectives for local people in a disadvantaged community - in a turbulent, and increasingly resource-constrained, context at a time when there is an increasing reliance on the third sector to provide opportunities to participate in sport. It presents unique insights gained longitudinally through an ethnographic case study centred on the specific sporting, socio-economic and political context of a single UK city. In some respects, this context is unique, and the city and its people are often presented as an exception to the rule, notably in sporting terms (Rookwood, 2011). Liverpool has however long been considered to represent a microcosm of the wider UK’s socio-economic problems (e.g., Boland, 2008, Harris, 1968; Meegan, 2003; Murden, 2006). Furthermore, the recent austerity-induced challenges facing the city are also currently mirrored in many other cities across the UK, and indeed many other countries across Europe (e.g., France, Germany, Greece, Italy, Spain, the Republic of Ireland, and Portugal). The case study therefore has relevance beyond this city in highlighting that resource-constrained contexts require managers of TSSOs to make 'better tactical and strategic decisions’ (Friedman et al. 2004, p.172) whilst being accountable to a much wider range of stakeholders than more profit-driven organisations (Taylor and Taylor,2014). The ethnographic approach has demonstrated the fluidity of these relationships and the varying salience of the different stakeholders over time and highlighted the importance of recognising the complex inter-play between 
the attributes of stakeholder power, legitimacy, and urgency. It indicates that flexibility to adapt to the changes in context is integral to the survival of TSSOs in the longer term, thereby ensuring that valuable community assets (including human capital) are retained and utilised effectively within the communities that need them the most, in order to maximise health and wellbeing outcomes through sport.

The founders of Target Football have continued to prioritise children, young people and their community as its most salient stakeholders throughout its lifetime and this has to date been instrumental in securing the success of the organisation. By remaining true to its aims and objectives the CIC is succeeding as a result of the mutually-beneficial relationships that have been developed with a variety of stakeholders in the local area - some of whom are described as both partners and competitors. These findings resonate with Walker and Hayton's (2016) study of the GSA, also operating in Liverpool where the authors describe how the GSA has navigated austerity by balancing financial ‘viability’ with operational ‘desirability’. Both TSSOs attribute their longevity to their refusal to deviate from their organisational vision which is not typical of other third sector organisations that reluctantly chase funding at odds with their core aims and objectives in order to survive (Hastings et al., 2015). Thus, future research might be aimed exploring this phenomenon further and, in particular, explore whether it is possible to retain such integrity (and success) when working with commercial partners.

The stakeholder theory framework is useful in that it prioritises the relationships that exist between managers of organisations and their stakeholders. Mitchell et al. (1997) state that stakeholder salience is dynamic, and not static, in the sense that stakeholder attributes are variable, and are socially constructed, and this has been reflected in the experiences of Target Football. As cuts continue to be implemented and 
funds grow scarcer the competition for available funds becomes fiercer and yet as a direct outcome of this TSSOs are also working more collaboratively through networks. These TSSOs are adopting strategies of specialisation in the services they offer in order to avoid duplication. Again, these experiences were reflected in the GSA study (Walker and Hayton, 2016). Future studies could usefully explore the evolution of these networks and the implications of TSSOs specialising in the services that they provide.

As austerity impacts both on the organisation and on the environment in which TSSOs operate this necessarily impacts both on the relationships with, and salience of, key stakeholders. Whilst the definitive stakeholders may be seen as having the highest priority, no stakeholder is being disregarded in this risky environment:

\footnotetext{
'So, keeping that relationship with the local community... is you know one of the main reasons why we've been so successful and why we have got a good relationship. Having said that, the relationships with you know our partners, the venues, the partnerships in the area, the local government, the police, they're all really important to us’ (Founder \#1, FIV).
}

Both Target Football and the GSA (Walker and Hayton, 2016) have recognised their relationships with schools as possibly providing routes to more sustainable income streams but again schools face their own on-going challenges with reductions in public spending.

Returning to David Cameron’s aspiration ‘to do more with less’ (in Krugman 2015, p.1) this study has indicated that TSSOs have been left with no option but to attempt this in order to try and backfill the increasing gaps in provision left by reductions in public services and to survive in the long term. This has however resulted in an increasingly precarious and vulnerable landscape for those involved to navigate and past success does not necessarily ensure future success. Without options for reliable 
and sustainable funding streams it seems likely that not all of the TSSOs who have survived to date will continue in the future and in the absence of alternatives this raises concerns about the resultant impact on the health and wellbeing of the disadvantaged communities these organisations serve.

To conclude then, the aim of the authors has been to present some insights in to the issues facing newly-emerged social enterprises in dealing with the uncertain environments created by austerity and changing policy contexts, to sustain sporting opportunities and provision in some of the most disadvantaged communities in the UK. Whilst it is recognised that the study has focused on only one organisation and is therefore limited in reach it has the advantage of being longitudinal. Importantly the findings of this research are congruent with earlier studies. Walker and Hayton (2016) point to the possibilities that have arisen as a result of the recent changes in sports policy in the UK (HM Government, 2015; Sport England, 2016) noting in particular Sport England's future reliance on partners that understand under-represented groups best. This reliance pre-supposes however organisations like Target Football (and the GSA), that know their groups best, are able to survive the challenges of austerity. The founders of Target Football question this assumption as they have seen other TSSOs flounder with the result that highly skilled and experienced staff are no longer able to undertake the work they do so well with the target groups that need them the most. In order to capitalise on the wealth of experiences and skills that currently reside in disadvantaged communities Sport England will need to ensure that they are able to successfully identify the organisations that have proven themselves to be sustainable in the long term if they are to avoid further disillusioning disadvantaged communities. 
Acknowledgements: The authors would like to thank Paul Hurford and Reg Standish, the founders and directors of Target Football CIC, for allowing us access to project and for sharing their experiences.

1. 'A community interest company (CIC) is a type of company, designed in particular for social enterprises that want to use their profits and assets for the public good. [...] They pursue social objectives, such as environmental improvement, community development and inclusion, fair trade, support services etc. [...] [They] can be established for any lawful purpose, as long as their activities are carried on for the benefit of the community' (Office of the Regulator of Community Interest Companies 2016, pp.6-7).

2. When the UK joined the European Economic Community in 1973, the city’s geographic location proved less convenient for trade with Europe than it had been for trade in the Atlantic.

3. Alongside Stavanger in Norway.

4. Lower Super Output Areas are geographic areas used by the Office for National Statistics 'for the collection and publication of small area statistics' - they typically contain an average of around 1,500 residents and 650 households (Office for National Statistics, n.d.).

5. For more information, please refer to: < https://www.nacro.org.uk/>

6. For more information, please refer to: < http://www.mya.org.uk/>

7. To allay ethical concerns, no data was collected from any individual under the age of 18.

8. For more information, please refer to: $<\underline{\text { http://www.help4teens.co.uk/advice/National- }}$

\section{Careers-Service.html>}

9. For more information, please refer to: $<\underline{\text { https://www.addaction.org.uk/ }>}$

10. For more information, please refer to: $<\underline{\text { http://www.active8supportservices.co.uk/ }>}$

\section{References}

Asenova, D., Bailey, S., \& McCann, C. (2015). Managing municipal austerity: 
mitigation of social risks. Local Government Studies, 41(1), 1-19.

http://doi.org/10.1080/03003930.2014.919268

Hastings, A., Bailey, N., Besemer, K., Bramley, G., Gannon, M., \& Watkins, D. (2013). Coping with the Cuts? Local Government and Poorer Communities. York, The Joseph Rowntree Foundation.

Jones, G., Meegan, R., Kennett, P., \& Croft, J. (2015). The uneven impact of austerity on the voluntary and community sector: A tale of two cities. Urban Studies, 53(April 2015), 1-17. http://doi.org/10.1177/0042098015587240

Barrett, G., \& McGoldrick, C. (2013). Narratives of (in)active ageing in poor deprived areas of Liverpool, UK. International Journal of Sociology and Social Policy, 33(5/6), 347-366.

Belchem, J. (2000). Merseypride: Essays in Liverpool Exceptionalism. Liverpool: Liverpool University Press.

Belchem, J. (ed.) (2006). Liverpool 800. Culture, Character, and History. Liverpool: Liverpool University Press.

Bichard, E. (2016). Liverpool case study. In, D. K. Carter (ed.) Remaking PostIndustrial Cities: Lessons from North America and Europe (pp.153-170). Oxon: Routledge.

Blakeley, G. \& Evans, B. (2013). The Regeneration of East Manchester: A Political Analysis. Manchester: Manchester University Press.

Boland, P. (2000). Urban governance and economic development: A critique of Merseyside and Objective 1 Status, 1994-1999. European Urban and Regional Studies, 7(3), 211-222. 
Boland, P. (2007). Unpacking the theory-policy interface of local economic development: An analysis of Cardiff and Liverpool. Urban Studies, 44(5-6), 1019-1039.

Boland, P. (2008). The construction of images of people and place: Labelling Liverpool and stereotyping Scousers. Cities, 25, 355-369.

Census (1991). 1991 English census data. <http://casweb.mimas.ac.uk> Accessed 25.11.2016

Clarkson, M.B.E. (1995). A stakeholder framework for analyzing and evaluating corporate social performance. Academy of Management Review, 20, 92-117.

Collins M., \& Haudenhuyse, R. (2014) Social exclusion and austerity policies in England: The role of sports in a new area of social polarisation and inequality? Social Inclusion, 3(3), 5-18.

Collins, M., \& Kay, T. (2014). Sport and Social Exclusion. Oxon: Routledge

Communities and Local Government (2004). Indices of Deprivation 2004. <http://webarchive.nationalarchives.gov.uk/20100410180038/http://www.comm unities.gov.uk/archived/generalcontent/communities/indicesofdeprivation/216309/> Accessed 25.11.2016

Communities and Local Government (2007). Indices of Deprivation 2007. <http://webarchive.nationalarchives.gov.uk/20100410180038/http://communitie s.gov.uk/communities/neighbourhoodrenewal/deprivation/deprivation07/> Accessed 25.11.2016

Cowley, J., Lea, D., Poplawski, P., Storer, R., Neill, E., Page, M., Entwistle, A., \& Brannigan, J. (2001). Modern literature. The Year's Work in English Studies, 80(1), 605-702. 
Curran, K., Bingham, D. D., Richardson, D., \& Parnell, D. (2014). Ethnographic engagement from within a Football in the Community programme at an English Premier League football club. Soccer \& Society, 15(6), 934-950.

Department for Local Communities and Government (2010). The English Indices of Deprivation 2010 <https://www.gov.uk/government/uploads/system/uploads/attachment_data/file/ 6871/1871208.pdf> Accessed25.11.2016

Department for Local Communities and Government (2015). The English Indices of Deprivation 2015 <https://www.gov.uk/government/uploads/system/uploads/attachment_data/file/ 465791/English_Indices_of_Deprivation_2015_-_Statistical_Release.pdf> Accessed 25.11.2016

Donaldson, T., \& Dunfee, T. W. (1999). Ties that Bind. Cambridge: Harvard University Press.

Egdell, V., \& Dutton, M. (2017). Third sector independence: relations with the state in an age of austerity. Voluntary Sector Review, 8(1), pp.25-40. http://doi.org/10.1332/204080516X14739278719772

Etzioni, A. (1964). Modern Organizations. Englewood Cliffs, NJ: Prentice-Hall.

Evans, T., Cummins, S., \& Brown, T., (2013). Neighbourhood deprivation and the cost of accessing gyms and fitness centres: national study in Wales. Health Place, 24, $16-19$.

Ferrari, E., \& Roberts, J. (2004). Liverpool - Changing urban form. In, Shrinking Cities (ed.) Manchester / Liverpool (pp.130-136). Berlin: Shrinking Cities.

Farrell, L., Hollingsworth, B., Propper, C., \& Shields, M. A. (2014). The socioeconomic gradient in physical inactivity: Evidence from one million adults in England. 
Social Science and Medicine, 123, 55-63.

http://doi.org/10.1016/j.socscimed.2014.10.039

Freeman, R. E. (1984). Strategic Management: A Stakeholder Approach. Boston, MA: Pitman.

Friedman, M.T., Parent, M.M., \& Mason, D.S. (2004). Building a framework for issues management in sport through stakeholder theory. European Sport Management Quarterly, 4(3), 170-190.

Grant Thornton (2015). The Annual Audit Letter for Liverpool City Council, http://www.psaa.co.uk/wpcontent/uploads/AAL/2015/Liverpool\%20City\%20Council.pdf

The Guardian (2015). Liverpool council faces stark choices as it looks into the financial abyss. <https://www.theguardian.com/society/2015/nov/10/liverpool-councilcuts-financial-abyss-budget> Accessed 25.11.2016

Harvey, B., \& Schaefer A. (2001). Managing relationships with environmental stakeholders: A study of U.K. water and electricity utilities. Journal of Business Ethics, 30, 243-260.

Hastings, A., Bailey, N., Besemer, K., Bramley, G., Gannon, M., \& Watkins, D. (2013). Coping with the Cuts? Local Government and Poorer Communities. York, The Joseph Rowntree Foundation.

Hastings, A., Bailey, N., Bramley, G., Gannon, M., \& Watkins, D. (2015). The Cost of the Cuts: The Impact on Local Government and Poorer Communities. York, Joseph Rowntree Foundation.

Hemmings, M. (2017). The constraints on voluntary sector voice in a period of continued austerity. Voluntary Sector Review, 8(1): pp.41-66. http://doi.org/10.1332/204080517X14870873219328 
Higgs, G., Langford, M., \& Norman, P. (2015). Accessibility to sport facilities in Wales: A GIS-based analysis of socio-economic variations in provision. Geoforum, 62, 105-120.

HM Government (2015). Sporting Future - A New Strategy for an Active Nation $<$ https://www.gov.uk/government/publications/sporting-future-a-new-strategyfor-an-active-nation> Accessed 03.06.17.

HM Treasury (2010). Spending Review 2010. London: The Stationery Office Limited. Hudson, B. (2006). University jazz and the Mersey Sound: Student days in Liverpool, a memoir. Popular Music History, 1(2), 215-226.

Jackson, E.L. (1994). Geographical aspects of constraints on leisure and recreation. Canadian. Geographer, 38(2),110-121.

Jones, A., Hillsdon, M., \& Coombes, E. (2009). Greenspace access, use, and physical activity: Understanding the effects of area deprivation. Preventative Medicine, 49(6), 500-505.

Jones, G., Meegan, R., Kennett, P., \& Croft, J. (2015). The uneven impact of austerity on the voluntary and community sector: A tale of two cities. Urban Studies, 53, $1-17$.

Jones, P., \& Wilks-Heeg, S. (2004). Capitalising culture: Liverpool 2008. Local Economy, 19(4), 341-360.

Kelly, L. (2010). ‘Social inclusion’ through sports-based interventions? Critical Social Policy, 31(1): 126-150.

Kennett, P., Jones, G., Meegan, R., \& Croft, J. (2015). Recession, austerity and the 'Great Risk Shift': Local government and household impacts and responses in Bristol and Liverpool. Local Government Studies, 41(4), 622-644. 
King, N. (2009). Sport Policy and Governance: Local Perspectives. Oxford: Butterworth Heinemann.

King, N. (2013). 'Sport for all' in a financial crisis: Survival and adaptation in competing organisational models of local authority sport services. World Leisure Journal, 55(3), 215-228.

Kokolakakis, T., Lera-Lopez, F., \& Castellanos, P. (2014). Regional differences in sports participation: the case of local authorities in England. International Journal of Sport Finance, 9(2), 149-171.

Krugman, P. (2015). The austerity drive in Britain isn’t really about debt and deficits at all; it’s all about using deficit panic as an excuse to dismantle social programs, New York Times.

Liverpool City Council (2015). The Index of Multiple Deprivation 2015: A Liverpool Analysis. Liverpool: Liverpool City Council.

Liverpool City Council (2016). Mayor's budget. <https://liverpool.gov.uk/budget> Accessed 25.11.2016.

Long, C., \& Williams, J. (2005). Football and music cultures in Liverpool. Esporte E Sociedade, 1(1), 1-43.

Macintyre, S., Macdonald, L., \& Ellaway, A. (2008). Do poorer people have poorer access to local resources and facilities? The distribution of local resources by area deprivation in Glasgow, Scotland. Social Science \& Medicine, 67(6), 900914.

Meegan, R. (2004). Urban regeneration, politics, and social cohesion: the Liverpool case. In, Shrinking Cities (ed.) Manchester / Liverpool (pp.140-162). Berlin: Shrinking Cities. 
Mitchell, R.K., Agle, B.R., \& Wood, D.J. (1997) Toward a theory of stakeholder identification and salience: Defining the principle of who and what really counts. The Academy of Management Review, 22(4), 853-886

Murden, J. (2004). Timeline: Liverpool 1699—2004. In, Shrinking Cities (ed.). (2004). Manchester / Liverpool (pp.118-129). Berlin: Editor.

Murden, J. (2006). City of change and challenge. Liverpool since 1945. In, J. Belchem (ed.) Liverpool 800. Culture, Character and History (pp. 393-485). Liverpool: Liverpool University Press.

National Audit Office (2014). The Impact of Funding Reductions on Local Authorities. London: Author.

Noonan, R.J., Boddy, L.M., Knowles Z.R., \& Fairclough, S.J. (2016). Cross-sectional associations between high-deprivation home and neighbourhood environments, and health-related variables among Liverpool children. BMJ Open, 6, e008693.

Office for National Statistics (n.d.). Super Output Areas explained <http://neighbourhood.statistics.gov.uk/dissemination/Info.do?page=nessgeogra phy/superoutputareasexplained/output-areas-explained.htm> Accessed 25.11.2016

Office of the Regulator of Community Interest Companies (2016). Frequently asked questions <https://www.gov.uk/government/uploads/system/uploads/attachment_data/file/ 605430/13-786-community-interest-companies-frequently-asked-questions.pdf> Accessed 03.06.17

Panter, J., Jones, A, \& Hillsdon, M. (2008). Equity of access to physical activity facilities in an English city. Preventative Medicine, 46(4), 303-307. 
Parent, M.M., \& Deephouse, D.L. (2007). A case study of stakeholder identification and prioritization by managers. Journal of Business Ethics, 75, 1-23

Parnell, D., Millward, P., \& Spracklen, K. (2015). Sport and austerity in the UK: An insight into Liverpool 2014. Journal of Policy Research in Tourism, Leisure and Events, 7(20), 200-203.

Parnell, D., Buxton, S., Hewitt, D., Reeves, M. J., Cope, E., \& Bailey, R. (2015). The pursuit of lifelong participation: the role of professional football clubs in the delivery of physical education and school sport in England. Soccer \& Society, 970, 1-17.

Rainer, P., Cropley, B., Jarvis, S., \& Griffiths, R. (2012). From policy to practice: the challenges of providing high quality physical education and school sport faced by head teachers within primary schools. Physical Education \& Sport Pedagogy, 17(4), 429-446.

Richardson, K., \& Rookwood, J. (2008) Partnerships, provision and product: examining the modern football in the community’ programme - a case study on Everton football club. Journal of Qualitative Research in Sports Studies, 2(1), 161-174.

Rookwood, J. (2011). 'We're not English we are Scouse!’ Examining the identities of Liverpool Football Club supporters. In, J. Hughson, C. Palmer, and F. Skillen (ed.) Sport and Social Identity: Studies from the Field. (pp. 95-120). New York: Edwin Mellen Press.

Sepulveda, L., Syrett, S., \& Calvo, S. (2013). Social enterprise and ethnic minorities: Exploring the consequences of the evolving British policy agenda. Environment and Planning C: Government and Policy, 31(4), 633-648.

Sport England (2016). Towards an Active Nation: Strategy 2016-2021. London: Author. 
Suchman, M. C. (1995). Managing legitimacy: Strategic and institutional approaches. Academy of Management Review, 20, 571-610.

Sykes, O., Brown, J., Cocks, M., Shaw, D., \& Couch, C. (2013). A city profile of Liverpool. Cities, 35, 299-318.

Target Football CIC (n.d.). About us <http://www.targetfootballcic.co.uk/about-us/> Accessed 25.11.2016

Taylor, M., \& Taylor, A. (2014). Performance measurement in the Third Sector: the development of a stakeholder-focussed research agenda. Production Planning \& Control, 25(16), 1370-1385.

Uduku, O. (1999). Beneficial redevelopment: a Cape Town-Liverpool comparison. Environment and Urbanization, 11(2), 95-111.

Walker, C., \& Hayton, J. (2016). Navigating austerity: balancing 'desirability with viability' in a third sector disability sports organisation. European Sport Management Quarterly, 17(1), 98-116.

Wilkinson, R.G. (1996). Unhealthy Societies: The Afflictions of Inequality. Routledge: London.

Wright, J., Martin, D., Cockings, S., \& Polack, C. (2006). Overall quality of outcomes framework scores lower in practices in deprived areas. British Journal of General Practice, 56(525), 277-279. 
Table 1 - Timeline of funding awarded to Target Football to deliver projects and services

\begin{tabular}{|c|c|c|c|}
\hline Date & Fund(er) (award) & Fund(er) Aim / Focus & Activity / Project \\
\hline Mar-11 & $\begin{array}{l}\text { Community Foundation for Merseyside - } \\
\text { Employable Communities Fund ( } £ 2720)\end{array}$ & Improving employment prospects & $\begin{array}{l}\text { Programme of employability workshops and FA Level } 1 \\
\text { Coaching Awards for young people aged 16-24 }\end{array}$ \\
\hline Mar-11 & $\begin{array}{l}\text { Community Foundation for Merseyside - } \\
\text { Police Property Act Fund (£2760) }\end{array}$ & $\begin{array}{l}\text { Increasing quality of life through crime } \\
\text { prevention }\end{array}$ & Staging a multi-cultural ‘World Cup’ football tournament \\
\hline Sep-11 & $\begin{array}{l}\text { Community Foundation for Merseyside - } \\
\text { Mersey Docks and Harbour Company } 500 \\
\text { Fund (£500) }\end{array}$ & $\begin{array}{l}\text { Building capacity for the community to help } \\
\text { itself }\end{array}$ & Equipment purchase (goals, footballs, cones, etc.) \\
\hline Nov-11 & $\begin{array}{l}\text { Sport England Small Grants Programme } \\
(£ 9450)\end{array}$ & $\begin{array}{l}\text { Increasing access to sport, and/or improving } \\
\text { the experience of those already taking part }\end{array}$ & $\begin{array}{l}\text { Football development programme for girls in local schools; } \\
\text { community based football sessions for women and girls; cre } \\
\text { and developing two women's teams; coach and volunteer tr }\end{array}$ \\
\hline Aug-12 & Hemby Trust ( $£ 1000)$ & Improving youth employment prospects & FA Level 1 Coaching Awards \\
\hline Sep-12 & Sported Small Grants (£2000) & $\begin{array}{l}\text { Improving youth employment prospects, and } \\
\text { crime prevention }\end{array}$ & $\begin{array}{l}\text { Programme of employability workshops and inclusive and } \\
\text { diversionary (free) football activities }\end{array}$ \\
\hline Nov-12 & $\begin{array}{l}\text { Littlewoods } 80^{\text {th }} \text { Birthday Gift Grant } \\
(£ 1000)\end{array}$ & $\begin{array}{l}\text { Supporting Liverpool's community groups } \\
\text { and charities }\end{array}$ & Equipment purchase (portable floodlights) \\
\hline Mar-13 & $\begin{array}{l}\text { Children in Need Small Grants Programme } \\
\text { (£29,223 over } 3 \text { years) }\end{array}$ & $\begin{array}{l}\text { Improving the lives of disadvantaged } \\
\text { children and young people }\end{array}$ & $\begin{array}{l}\text { A programme of employability workshops and FA Level } 1 \\
\text { Coaching Award for young people aged 16-24, as well as } \\
\text { inclusive and diversionary (free) football activities }\end{array}$ \\
\hline Apr-13 & $\begin{array}{l}\text { BIG Lottery Reaching Communities } \\
\text { (£195,663 over } 3 \text { years) }\end{array}$ & Improving disadvantaged communities & $\begin{array}{l}\text { Grassroots football development programme, inclusive and } \\
\text { diversionary (free) football activities, and training and } \\
\text { development programmes. }\end{array}$ \\
\hline
\end{tabular}


Jun-13 Austin Smith Memorial Small Grants Fund (£500)

Sep-13 Street Games Doorsteps Sports Clubs ( $£ 5,400$ over 3 years)

Jul-14 Sport England - Active 8 (£5,000 over 3 years)

Nov-14 FA Mash Up (£1,050 over 3 years)

Feb-16 Community Foundation for Merseyside Peel Ports 500 Fund (£500)

Apr-16 Children in Need Small Grants Programme (£48,384 over 3 years)

Apr-16 Community Foundation for Merseyside Police Property Act Fund (£1650)

Jun-16 Morgan Foundation (£60,000 over 3 years)

Sep-16 Sport England Small Grants Programme (£7935)

Nov-16 Lloyds Social Entrepreneurs Programme Scale Up Programme (£15000)
Developing stronger communities (focussing in the L8 area)

Staying active and developing a sporting habit for life

Developing sport and physical activity opportunities for young people aged 14-25

To increase participation in football by young people aged 14-25

Local need for the proposed project

Make a difference in the lives of disadvantaged children and young people

Increasing quality of life through crime prevention

Improving quality of life for young people

Developing sport and physical activity opportunities for young people aged 14-25

Sustaining and supporting social enterprises
League fees, club affiliation and equipment

Football coaching for young people aged 14+.

Girls football coaching and women's fitness classes

Inclusive and diversionary (free) football activities

Equipment purchase (full size goals)

A programme of employability workshops, and education and training for young people aged 16-24, as well as inclusive and diversionary (free) football activities

League fees for futsal team made up of local young people aged 15-18

Salary - Youth Inclusion Officer

Women and girls football coaching sessions

Salary - Football Development Officer 
Table 2 - Example services and projects of Target Football

\begin{tabular}{l} 
Example Services \\
\hline First-Time Soccer \\
Fun and inclusive football games that develop \\
movement, flexibility and core stability. Sessions \\
include simple problem-solving activities that aim \\
to improve children’s attention, listening and social \\
skills. \\
$\begin{array}{ll}\text { Day / time: } & \text { Saturday 10am-11am } \\
\text { Age group: } & \text { 2-4 (male and female) } \\
\text { Cost: } & £ 3 \text { per session }\end{array}$
\end{tabular}

\section{Soccer Saturdays}

Includes fun and inclusive games that develop movement, flexibility, and core stability. Sessions are designed to develop technique by using appropriate practises that challenge individual players and enhance their social and psychological development.

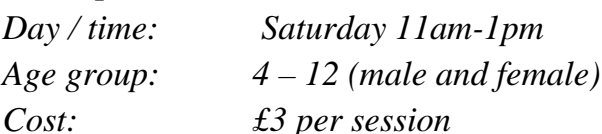

\section{Soccer Camps}

Sessions include: skill development and technical coaching; speed, agility and quickness training; goalkeeper training; mini-soccer matches; and, a World Cup Tournament.

Day / time:

Monday to Friday during school holidays, 11am-1pm(4 to 6

years), $\quad 11 \mathrm{am}-3 \mathrm{pm}$ (7 to 12 years)

Age group: $\quad 4-12$ (male and female)

Cost: $\quad £ 4$ per session (4 to 6 years), $£ 6$

(7 to 12 years)
Example Projects

\section{Primary Schools Footbal}

The programme includes 10 weeks of free football coaching for each school engaged with the project, and the opportunity to play in an inter school league.

Day / time: $\quad$ Wednesday afternoons

Age group: $\quad$ 7-11 (male and female)

Funded by: $\quad$ Big Lottery Fund (2013-2016)

\section{Detached Football Project}

The project provides young people from local communities with support on issues around employability using football as the first step of engagement. The programme aims to encourage positive attitudes towards education, training and employment. The football sessions include structured football coaching and team games in a safe environment.

Day / time: $\quad$ Tuesdays \& Thursdays, 5pm-7pm Age group: $\quad$ 16-24 (male and female)

Funded by: $\quad$ Children in Need (and previously, the Big Lottery Fund, 2013-2016)

\section{5+ Veteran Football}

The project aims to improve self-esteem and healthy lifestyles in marginalised and isolated adults. Sessions include: weekly training sessions, walking football, and five-a-side games. The project includes volunteer opportunities on other Target Football programmes. The project also offers community drop-in sessions and one-to-one appointments, and engages in outreach work.

Day/time: $\quad$ Thursday $5 \mathrm{pm}-7 \mathrm{pm}$

Age group: $\quad 35+$ (male)

Funded by: $\quad$ Delivered in partnership with the Liverpool Football Club Foundation's Military Veterans Programme 
Table 3 - Participants on Target Football's services and projects funded (directly or indirectly) by the Big Lottery, 2013-2016

\begin{tabular}{lc}
\hline Services / Project & n \\
\hline Soccer Saturdays & 453 \\
Women's Football & 81 \\
Managed Grassroots Teams (Admiral Park) & 129 \\
Detached Football & 134 \\
Primary Schools Football League & 648 \\
Volunteer Development - FA Level 1 Coaching Courses & 76 \\
35+ Veteran Football & 75 \\
\hline Total & $\mathbf{1 5 9 6}$
\end{tabular}

NB: These figures were reported back the National Lottery in the end-of-project monitoring and evaluation report. 